\title{
Production and decay of viruses in aquatic environments
}

\author{
Mikal Heldal, Gunnar Bratbak* \\ Department of Microbiology and Plant Physiology, University of Bergen, Jahnebakken 5, N-5007 Bergen, Norway
}

\begin{abstract}
The quantitative significance of aquatic viruses in coastal and in lake water was investigated. The number of viruses in marine surface waters was found to change on a diurnal basis along with changes in number of bacteria and bacterial activity. By inhibiting the production of viruses, we were able to measure viral decay rates up to $1.1 \mathrm{~h}^{-1}$ in marine systems, and up to $0.6 \mathrm{~h}^{-1}$ in a freshwater lake, for the majority of the viral population. A minor fraction $(4$ to $40 \%$ ) of the viral population was found to have decay rates lower than $0.05 \mathrm{~h}^{-1}$ The fraction of bacteria containing mature virus particles ranged from 2 to $16 \%$, and the number of viruses released from these bacteria was on average about 50 (range 10 to 300 ). From these results we estimate that phages may lyse 2 to $24 \%$ of the bacterial population per hour. Phages may thus be a major cause of bacterial mortality in aquatic ecosystems and may have a significant impact on the carbon and nutrient flow in aquatic food webs.
\end{abstract}

\section{INTRODUCTION}

The number of viruses in marine waters has been shown to be $10^{4} \mathrm{ml}^{-1}$ or higher (Torrella \& Morita 1979). It was later demonstrated that the number of viruses may vary both with location and time from less than $10^{4}$ to more than $10^{7} \mathrm{ml}^{-1}$ (Sieburth et al. 1988, Bergh et al. 1989, Proctor \& Fuhrman 1990, Bratbak et al. 1990), and that up to $7 \%$ of marine bacteria may contain mature phage particles (Proctor \& Fuhrman 1990). The quantitative importance of viruses in aquatic ecosystems is however still poorly understood.

Currently there is no method available for measuring rates of viral production in aquatic environments. The method we introduce in this paper is in principle similar to methods that have been used for measuring bacterial growth and protozoan grazing: by arresting production (or consumption) we can measure consumption (or production) and thereby estimate the production (or consumption). Several different treatments, including specific eucaryotic and procaryotic inhibitors, filtration and dilution have been used for arresting bacterial production and protozoan grazing (Wright \& Coffin 1984, Ducklow \& Hill 1985, Sanders \& Porter 1986, Sherr et al. 1986). In this study we used cyanide to inhibit the production of viruses and, by

\footnotetext{
- Author for correspondence
}

observing how fast the viral particles decay and disappear, we could estimate the production rate.

The reason for using cyanide as an inhibitor in this investigation was that its mode of action is well known and that it is a very efficient inhibitor of aerobic respiratory bacteria. Cyanide has in addition been widely used as an inhibitor in viral research and it has been shown not to inactivate free phage particles (Doermann 1952). Cyanide inhibits the production of phages while cell lysis and release of mature phage particles may continue (Doermann 1952, Symonds 1957). The full effect of cyanide may therefore not be observed before bacteria containing mature phage particles at the start of the experiments have lysed. Any change in viral concentration seen initially in the decay experiments will therefore depend on the balance between viral production and decay in the water at the time of sampling.

The rate of viral-induced mortality may be estimated from the rate of viral production when the burst size, i.e. number of viruses released from each individual host organism, is known. The burst size of bacteria may be estimated by inducing lysis from without and counting the phages released.

In this paper we present the results from a diurnal study where we made observations of short-time variations in viral numbers, enabling us to make minimum estimates of viral production and decay. Furthermore, 
we measured the rate of viral decay in several different environments and have estimated the rate of viralinduced bacterial mortality. Results, and their implications, are discussed in relation to current methods for measuring bacterial production and protozoan grazing, and in relation to our current view on the structure and function of microbial food webs.

\section{MATERIALS AND METHODS}

Diurnal study. A diurnal study of bacteria and viruses was performed in water from the bay off the Department of Marine Biology (University of Bergen) adjacent to Raunefjorden, Western Norway (Bratbak et al. 1990), on May 5 to 6, 1990. Polyethylene tanks of $60 \mathrm{l}$ capacity were used as enclosures (sea bags) to ensure that any change would be due to biological activity and not to patchiness of drifting surface water. Two enclosures, one wrapped in several layers of black plastic foil to exclude light, were filled with surface water at night, $11 \mathrm{~h}$ before start of the experiment and moored in the sea to a floating frame. Both enclosures were sampled every second hour for $24 \mathrm{~h}$.

Samples for counting of viruses and bacteria $(100 \mathrm{ml})$ were preserved with $1 \%$ glutaraldehyde (final concentration). Bacteria were counted in the epifluorescence microscope after staining $5 \mathrm{ml}$ subsamples with DAPI (Porter \& Feig 1980). Viruses were harvested onto electron microscope grids in duplicate by centrifugation and counted in the transmission electron microscope as previously described (Børsheim et al. 1990, Bratbak et al. 1990). Thymidine (TdR) incorporation (Fuhrman \& Azam 1982) was measured in duplicate samples (10 ml) incubated for $30 \mathrm{~min}$ in situ with $15.5 \mathrm{nmol}{ }^{3} \mathrm{H}$-labeled TdR $1^{-1}$. Glutaraldehyde ( $1 \%$ final concentration) was added to blanks and at the end of incubations. Radioactivity in cold TCA-precipitated material collected on 0.2 um pore size cellulose nitrate filters (Sartorius) was measured. Data on global radiation was obtained from measurements at Geophysical Institute, Department of Meteorology, University of Bergen.

Viral decay experiments and induction of lysis in bacteria. Water samples for these experiments were collected with a Ruttner water sampler between 08:00 and 10:00 $\mathrm{h}$ at the following locations (Table 1): in Raunefjorden, Western Norway (Bratbak et al. 1990); at the Dept of Marine Biology harbour, which lies in a bay adjacent to Raunefjorden, $20 \mathrm{~km}$ southwest of Bergen (Bratbak et al. 1990); in Bergen harbour area; and in Lake Kalandsvannet which is a $3.4 \mathrm{~km}^{2}$ oligotrophic freshwater lake with a mean depth of $37 \mathrm{~m}, 20 \mathrm{~km}$ south of Bergen. The experiments were in most cases started immediately after sampling and always within $1 \mathrm{~h}$ after sampling

All incubations for decay experiments were made in 1 or 51 bottles and at in situ temperature. The viral decay, i.e. decrease in viral concentration over time, was recorded after inhibiting production of new viruses by adding $\mathrm{KCN}$ to a final concentration of $2 \mathrm{mM}$ (Doermann 1952, Symonds 1957). The $\mathrm{pH}$ of the KCN stock solutions were adjusted to 7.0 for use in freshwater, and to 8.5 for use in seawater. Samples $(100 \mathrm{ml})$ for counting of viruses were withdrawn at intervals down to $30 \mathrm{~min}$. The samples were preserved and the viruses counted as described for the diurnal study. To investigate possible effects of cyanide on the viral decay measurements we performed control experiments where the viral production was arrested by removing possible host organisms by centrifugation at $16000 \times g$ for $20 \mathrm{~min}$. The experimental protocol was otherwise unchanged. The viral decay rate was calculated from the log-linear part of the decay curves using linear regression.

Bacteria containing mature phage particles were lysed from without using streptomycin (Symonds 1957, Symonds 1968). This made it possible to count both the frequency of bacteria containing mature phage particles and the number of phages released from the bac-

Table 1 Numbers of bacteria and viruses, virus decay rates and percent bacteria with mature phage particles

\begin{tabular}{|c|c|c|c|c|c|c|c|}
\hline $\begin{array}{l}\text { Location } \\
\text { (Norway) }\end{array}$ & $\begin{array}{l}\text { Date } \\
(1990)\end{array}$ & $\begin{array}{l}\text { Depth } \\
(\mathrm{m})\end{array}$ & $\begin{array}{l}\text { Temperature } \\
\left({ }^{\circ} \mathrm{C}\right)\end{array}$ & $\begin{array}{c}\text { Bacteria } \\
\left(10^{6} \mathrm{ml}^{-1}\right)\end{array}$ & $\begin{array}{l}\text { Viruses } \\
\left(10^{7} \mathrm{ml}^{-1}\right)\end{array}$ & $\begin{array}{c}\text { Viral decay } \\
\text { rate }\left(S E_{1} n\right)^{a} \\
\qquad\left(h^{-1}\right)\end{array}$ & $\begin{array}{l}\text { Bacteria with } \\
\text { mature phage } \\
\text { particles }(\%)\end{array}$ \\
\hline \multicolumn{8}{|l|}{ Dept of Marme } \\
\hline Biology harbour & 6 Jun & Surface & 12 & 4.4 & 4.4 & $0.30(0.01,4)$ & $\mathrm{ND}$ \\
\hline Bergen Harbour & 8 Jun & 1.5 & 13 & 2.9 & 5.9 & $1.1 \quad(0.2,3)$ & ND \\
\hline Raunefjorden & 19 Jun & Surface & 14 & 1.4 & 3.5 & $0.49(0.02,6)$ & 13 \\
\hline Raunefjorden & 19 Jun & 5 & 14 & 1.5 & 2.8 & $0.55(0.03,5)$ & 14 \\
\hline Raunefjorden & 19 Jun & 25 & 8 & 0.7 & 1.1 & $0.26(0.002,3)$ & 8 \\
\hline Lake Kalandsvannet & 17 Aug & 0.5 & 17 & 3.0 & 20.2 & $0.35(0.05,3)$ & 16 \\
\hline Lake Kalandsvannet & 28 Aug & 1 & 16 & 4.1 & 15.4 & $0.64(-.2)$ & 4 \\
\hline Lake Kalandsvannet & 28 Aug & 25 & 5 & 0.8 & 1.9 & $0.33(0.08,4)$ & 2 \\
\hline
\end{tabular}


teria. Water samples $(100 \mathrm{ml})$ were incubated immediately after sampling with $0.3 \% \mathrm{w} / \mathrm{v}$ streptomycin (Sigma No. S-6501) for $1 \mathrm{~h}$ and then harvested onto grids in duplicate and prepared for electron microscopy as described for total counting of viruses (Borsheim et al. 1990, Bratbak et al. 1990).

\section{RESULTS}

\section{Counting accuracy and precision}

The accuracy of our virus counting method was tested using the coli phage $T_{4}$ as a standard. The number of plaque-forming units in a fresh lysate was found to be 85 to $90 \%$ of the number of countable phage particles (data not shown). This discrepancy may be due to the presence of inactive phages or to the presence of clumps of active phages which will give rise to only one plaque (Luria et al. 1951). The conclusion is nevertheless that our counting method gives us close to $100 \%$ recovery of virus particles.

When counting viruses in natural waters (Fig. 1) the standard deviation of parallel preparations was 1 to $29 \%$ (mean: $16 \%$ ), and the counting error was 4 to 13 $\%$. The precision of our virus counting method may also be judged from the standard error of the decay rates (Table 1). On this basis we conclude that our virus data are sufficiently precise and accurate.

\section{Diurnal study}

Results from the diurnal study are shown in Fig. 1. The pattern of change in bacterial concentration was similar in the 2 enclosures (Fig. 1B, C). The concentration decreased from the start of the experiment (09:00 h), reached a minimum in the afternoon at 15:00 $\mathrm{h}$ and increased throughout the evening and night.

The viral concentration in the light-exposed enclosure (Fig. 1B) peaked at noon and during the daylight period (06:00 to 21:00 h) was significantly correlated with the global radiation (Fig. 1A) $(r=0.725, n=0.8, p<0.05)$. The viral concentration in the dark enclosure (Fig. 1C) showed a marked diurnal variation with a maximum value in the afternoon (15:00 to 17:00 h). The number of viruses in this enclosure was correlated with thymidine incorporation (Fig. 1D) $(r=0.584, n=12, p<0.05)$ and with thymidine incorporation per bacterium ( $\mathrm{r}=0.799$, $\mathrm{n}=12, \mathrm{p}<0.01)$. We found no significant correlation between number of bacteria and number of viruses.

From the changes in viral concentration observed in the diurnal study (Fig. 1B, C) we may calculate viral production rates up to $0.36 \mathrm{~h}^{-1}$, and viral decay rates up to $0.32 \mathrm{~h}^{-1}$. These rates are minimum estimates since they are based on net changes in viral concentration.

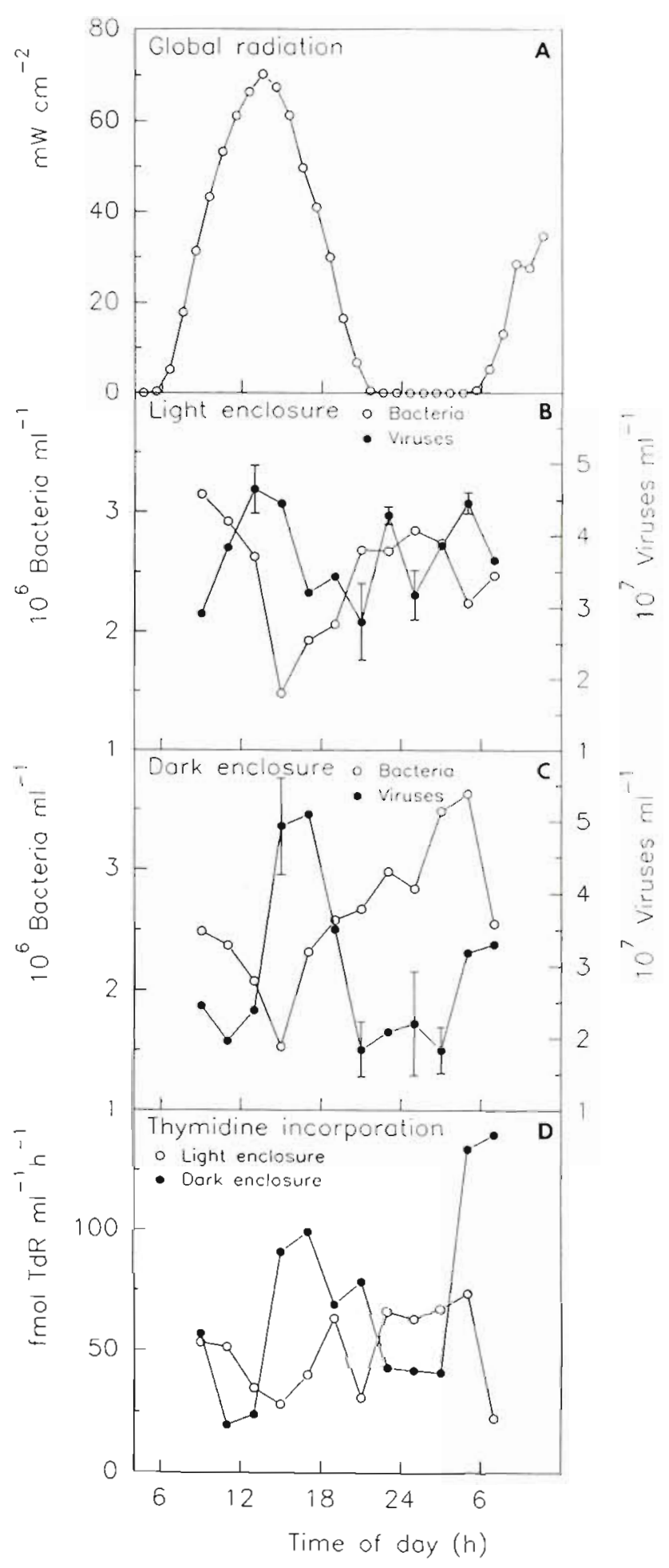

Fig. 1. Diurnal changes in (A) global radiation, $(B, C)$ number of bacteria and viruses, and (D) thymidine (TdR) incorporation in one light-exposed and one dark $60 \mathrm{l}$ seawater enclosure, Raunefjorden, western Norway, May 5 to 6, 1990 


\section{Viral decay experiments and induction of lysis in bacteria}

Cyanide has no significant effect on the viral decay rate compared to the decay rate observed when removing possible host organisms by centrifugation (Fig. 2A).

In the decay experiments shown in Fig. 2A, B we

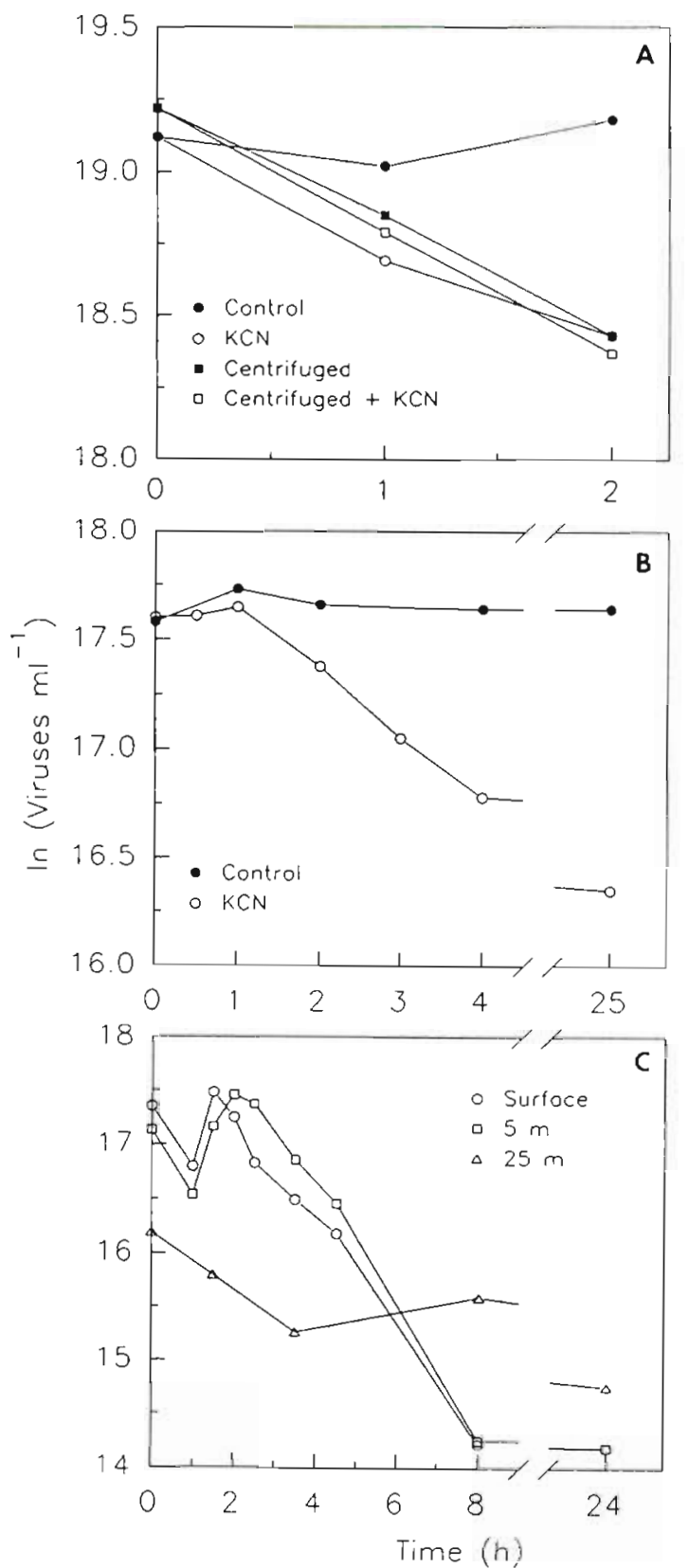

Fig. 2. Changes in viral counts as a function of time after arresting the production of viral particles. (A) Comparative study of viral decay after cyanide addition and after removing possible host organisms by centrifugation. Sample from Lake Kalandsvannet, Norway, August 17, 1990. (B, C) Viral production inhibited with cyanide. Samples from (B) Dept of Marine Biology harbour, June 6, and (C) Raunefjorden, June 19, 1990 observed no significant changes in viral concentration in the control bottles receiving no treatment. This indicates that production and decay of viruses in these cases were in balance during the incubation.

The decay observed in the $\mathrm{KCN}$ bottles during the first 2 to $8 \mathrm{~h}$ of the incubations can be described as exponential (Fig. 2). Viral decay rates, which may be calculated from the log-linear part of the decay curves ranged from 0.3 to $1.1 \mathrm{~h}^{-1}$ (Table 1 ). These rates are in agreement with the minimum rates estimated from the diurnal study. The rate of viral decay decreased to less than $0.05 \mathrm{~h}^{-1}$ after 4 to $8 \mathrm{~h}$ when 4 to $40 \%$ of the initial viral population remained (Fig. $2 \mathrm{~B}, \mathrm{C}$ ). The majority of the viral population ( $>60 \%$ ) thus has a relatively short turnover time, while a minor fraction $(<40 \%)$ is relatively refractile. This latter fraction was usually dominated by larger viruses with head diameter $>60 \mathrm{~nm}$.

Both in Lake Kalandsvannet and in Raunefjorden, the rate of viral decay was found to be higher above the thermocline than below the thermocline (Table 1). This may indicate that the viral decay is directly or indirectly related to physical, chemical or biological factors in the environment.

A high viral decay rate implies a high rate of production of new viruses and thus that host organisms containing mature viral particles should be frequent. Lysing infected bacteria from without using streptomycin we found that 2 to $16 \%$ of the bacteria contained mature phage particles (Table 1). These phage particles (Fig. 3) appeared similar to the free viral particles counted in the diurnal study and in the decay experiments, suggesting that the free viral population was dominated by phages. The number of phages released from lysed bacteria was on the average about 50 (range 10 to 300 ).

\section{DISCUSSION}

\section{Diurnal study}

It is reasonable to believe that most phages in aquatic environments are temperate rather than virulent (Freifelder 1987, Bratbak et al. 1990). The rate of phage production will thus depend on the rate of induction in lysogenic bacteria rather than on the rate of infection. If phage production in many lysogenic bacteria is induced by the same environmental factors we may expect the phage production in aquatic environments to be synchronous, and thus that the number of free phages and the number of bacteria containing mature phage particles fluctuate.

The results from the diurnal study (Fig. 1) show that the viral population density in marine waters may change significantly on a time scale of hours. The viral 


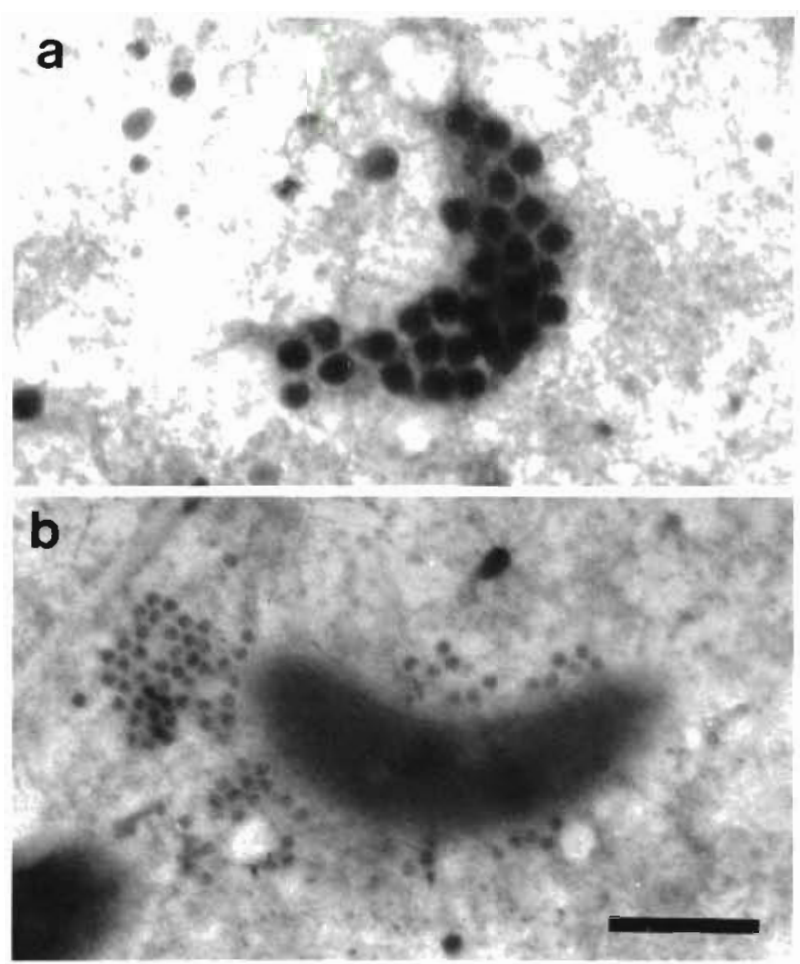

Fig. 3. Artificially lysed bacteria. (a) Bacterium with phage particles, head diameter ca $100 \mathrm{~nm}$. (b) Bacterium surrounded by phage particles, head diameter ca $30 \mathrm{~nm}$. Scale bar $=$ $0.5 \mu \mathrm{m}$

population is thus a dynamic member of the microbial community in aquatic ecosystems and may change on the same time scale as other microbial parameters (e.g. primary production, bacterial numbers, thymidine incorporation and dissolved DNA concentration) in some environments (Paul et al. 1988, Jeffrey et al. 1990). Light and nutrient availability are among the environmental factors which may induce lysogenic bacteria to produce and liberate viruses. A simple interpretation of the correlations between viral numbers and light and between viral numbers and thymidine incorporation in the diurnal study (Fig. 1) is that the viral production is governed directly or indirectly by light during daytime, while in the dark it is governed by the bacterial activity. However, the enclosure experiment was not rurı with replicates and it is therefore not possible to reject the hypothesis that the results obtained are differences between 2 similar bags. The results may thus also be interpreted in terms of diurnal rhythms rather in terms of light as a factor per se.

An overall negative correlation between number of bacteria and number of viruses could be expected if the bacterial population was controlled by viral-induced lysis. This correlation may be obscured, however, if the phage production in subpopulations of bacteria with widely different burst sizes is controlled by different environmental parameters, or if the viral decay rate is high compared to the sampling interval or to the bacterial growth rate. Protozoan bacterivory, which is a ubiquitous phenomenon in marine ecosystems, may also obscure the correlation between bacterial and viral numbers.

The bacteria in the 2 enclosures may be estimated from the measured thymidine incorporation to grow at an average rate of $0.6 \mathrm{~d}^{-1}$ (range: 0.2 to $1.4 \mathrm{~d}^{-1}$ ), assuming a conversion factor of $1 \times 10^{18}$ cells per mol $T d R$ incorporated. These growth rate estimates are reasonable compared to literature data on bacterial growth in aquatic ecosystems (Ducklow \& Hill 1985. Moriarty 1986). However, molecular fractionation and isotope dilution analysis was not performed, and we did not determine an empiric conversion factor relating thymidine incorporation to cell production for the environment we were investigating. The overall range in published empiric conversion factors is more than 10-fold, whereas conversion factors determined using high (>10 $\mathrm{nM}$ ) thymidine concentrations, and conversion factors determined for particular environments during a particular season, are often more congruent (Riemann et al. 1987, Bell 1990, Riemann \& Bell 1990). There is addition a wide discrepancy ( $>>10$-fold) between theoretical and empirical conversion factors (Bell 1990). Considering the uncertainty in the conversion factor, our bacterial growth rate estimates cannot be regarded as more accurate than to within a factor of 3 to 5 .

\section{Viral decay experiments and induction of lysis in bacteria}

Using the approach we applied to measuring viral production, it must be ascertained that the processes measured are not affected by the treatment of the samples. This is a serious problem when dealing with biological processes such as bacterial growth or protozoan grazing (Taylor \& Pace 1987, Tremaine \& Mills $1987 \mathrm{a}$, b). Using cyanide we reduced the possibility that biological processes may affect the measured decay. If the viral decay to some extent, directly or indirectly, depends on energy-requiring biological processes, the rate of decay would be systematically underestimated. Nevertheless, considering the fact that cyanide has been widely used as an inhibitor in viral research and the results from the control experiment showing that cyanide has no significant effect on the viral decay rate, we conclude that cyanide is an adequate metabolic inhibitor for our viral decay experiments.

A steady decrease in viral concentration was in some decay experiments not observed until 1 to $2 \mathrm{~h}$ after addition of cyanide (Fig. 2b, c). This may be explained 
as a consequence of the fact that cyanide inhibits the production of phages while cell lysis and release of mature phage particles may continue (Doermann 1952, Symonds 1957).

The fate of the viral particles is unknown. One possibility is that their nucleic acid is ejected or otherwise released. Any empty capsides will not be recognized by the methods we have used. Release of DNA and RNA from cells during lysis and from free phage particles may contribute to the concentration of nucleic acids in aquatic habitats (Karl \& Bailiff 1989). Paul et al. (1988) observed a diel periodicity in microbial activity and in dissolved DNA in a subtropical estuary. The dissolved DNA production lagged behind the maximum in bacterial activity by ca $4 \mathrm{~h}$. These observations may be explained by a diel periodicity in viral production and by release of DNA from decaying viral particles.

Streptomycin is an inhibitor of protein synthesis and will also stop phage maturation (Symonds 1957). High concentrations of streptomycin will in addition induce bacterial lysis (Symonds 1968). We have no reason to believe that all bacteria are affected to the same extent by the streptomycin treatment. The fraction of bacteria containing mature phage particles detected by this method must therefore be regarded as a minimum estimate. The number of mature phage particles released from the lysed bacteria must also be regarded as a minimum estimate of burst size because the streptomycin terminates phage maturation and lyses the cells before the latent period is over.

\section{Rate of bacterial growth and mortality}

Protozoan grazing is generally assumed to be the most important cause of bacterial mortality in aquatic ecosystems. The rate of grazing may however not always be sufficient to explain the mortality of bacteria and does not always balance the bacterial production (Servais et al. 1985, McManus \& Fuhrman 1988, Pace 1988, Servais et al. 1989, Sherr et al. 1989). This discrepancy may be due to viral-induced bacterial mortality.

If the viral population density is to be maintained, we may, from the data given in Table 1 , estimate that phages must lyse 2 to $24 \%$ of the bacterial population per hour, assuming a burst size of 50 to 100 new phages per lysed bacterium and (conservatively) that $50 \%$ of the viral population decays at the rates indicated. The bacteria must grow at a rate of 0.4 to $6 \mathrm{~d}^{-1}$ to balance this viral-induced mortality These growth rate estimates are relatively high compared to the bacterial growth rates measured in most aquatic ecosystems (Ducklow \& Hill 1985, Moriarty 1986) indicating that current estimates of protozoan grazing may be overestimated, or that current estimates of bacterial produc- tion may be underestimated. The diel periodicity in the viral concentration we observed in the diurnal study suggests a diel periodicity in the rate of production or in the rate of decay of the viral particles. We cannot therefore claim that our viral decay measurements, which were all made on water samples taken in the morning, are representative of the daily average.

The phages released in a single burst may be calculated to contain 1.5 to 3 times as much DNA as a single bacterium, assuming the burst size to be 50 to 100 and the DNA content of individual bacteria and phages to be 2.6 and $0.08 \mathrm{fg}$ respectively (Fuhrman \& Azam 1982, Børsheim et al. 1990). Considering the rates of virus production we have estimated, this suggests that the basis for estimating the rate of bacterial growth in aquatic ecosystems from the rate of DNA synthesis (Fuhrman \& Azam 1980, Fuhrman \& Azam 1982) may be questioned.

${ }^{3} \mathrm{H}$-thymidine incorporation has been widely used for measuring the rate of DNA synthesis in bacteria in aquatic environments (Moriarty 1986, Riemann \& Bell 1990). In its current form, this method does not discriminate between production of bacterial DNA, viral DNA and dissolved DNA released during lysis of bacteria. The thymidine method therefore in principle measures total DNA synthesis in bacteria. Rates of thymidine incorporation are converted to cell production using conversion factors. Conversion factors may be derived from simultaneous measurements of thymidine incorporation and observations of cell number increase in cultures of natural bacterial populations where bacterivory has been prevented by filtration and dilution (Riemann \& Bell 1990). Cells lost due to viralinduced lysis will not be included in the calibration and the cell number increase is therefore net production. The conversion factor will thus relate the total rate of DNA synthesis in bacteria to the net bacterial cell production. Consequently, viral-induced bacterial mortality will contribute to the variability in the conversion factors (Bell 1990, Riemann \& Bell 1990) and to the uncertainty in the production estimates.

The methods used for measuring the protozoan grazing will not detect viral-induced bacterial mortality. Most phages are presumably temperate and present as prophages in bacteria, and their possible impact on the bacterial population is therefore not affected by dilution or filtration (Wright \& Coffin 1984, Ducklow \& Hill 1985). Procaryotic inhibitors (Sanders \& Porter 1986. Sherr et al. 1986) will also inhibit phage production and thus preclude detection of any viral-induced mortality. Eucaryotic inhibitors (Taylor \& Pace 1987) will in principle not affect the viral production, and the viralinduced mortality will be the same in the experimental bottle as in the control bottle, i.e. viral-induced mortality is not detected. 
These considerations on production and consumption of bacterial biomass make it important to distinguish between net and total bacterial production. Net production refers to the bacterial biomass that may be harvested as particles by protozoan grazing. Total production includes in addition the biomass of the viral particles and the organic material released from the bacteria as dissolved organic material during lysis. The bacterial production removed by viral-induced lysis may enter the pool of dissolved organic material (DOM) utilized mainly by bacteria and be recycled in a bacteria-phage-DOM loop (Bratbak et al. 1990). One implication of this is that the bacterial production released due to viral-induced lysis is in part selfsustained. Assuming $50 \%$ respiration, the carbon input required for phage production will be half that required for harvestable (net) production.

Viruses uncouple production and consumption of particulate biomass and they increase the production of DOM. They may thus be a key factor for understanding the transformation between the particulate, colloidal and dissolved fractions of organic material in seawater (Sugimura \& Suzuki 1988, Isao et al. 1990). The high rate of viral decay suggests that transformation rather than transduction may be the predominating pathway for genetic exchange between bacteria in natural aquatic environments. The ecological significance of algal and protozoan viruses remains to be investigated.

Acknowledgement. This work was supported by the Norwegian Research Council for Science and Humanities and the Norwegian Fisheries Research Council. The electron microscope work was done at the Laboratory for Electron Microscopy, Science Faculty. We thank Eva-Britt Hiltun and Marianne Jorstad for technical assistance during the enclosure experiment. We also thank Ian Dundas, Svein Norland and Frede Thingstad for helpful discussions and suggestions.

\section{LITERATURE CITED}

Bell, R. T. (1990). An explanation for the variability in the conversion factor deriving bacterial cell production from incorporation of $\left[{ }^{3} \mathrm{H}\right]$ thymidine. Limnol. Oceanogr 35: 910-915

Bergh, Ø., Børsheim, K. Y., Bratbak, G., Heldal, M. (1989). High abundance of viruses found in aquatic environments. Nature, Lond. 340: 467-468

Bratbak, G., Heldal, M., Norland, S., Thingstad, T F. (1990). Viruses as partners in spring bloom microbial trophodynamics. Appl environ. Microbiol 56: 1400-1405

Borsheim, Y., Bratbak, G., Heldal, H. (1990). Enumeration and biomass estimation of planktonic bacteria and viruses by transmission electron microscopy. Appl. environ. Microbiol. 56: 352-366

Doermann, A. H. (1952). The intracellular growth of bacteriophages. J. gen. Physiol. 35: 645-656

Ducklow, H. W., Hill, S. M. (1985). The growth of heterotrophic bacteria in the surface waters of warm core rings. Limnol. Oceanogr. 30: 239-259
Freifelder, G. (1987). Microbial genetics. Jones and Bartlett Publishers Inc., Boston

Fuhrman, J. A., Azam, F. (1980). Bacterioplankton secondary production estimates for coastal waters of British Columbia. Antarctica, and California. Appl. environ. Microbiol. 39: 1085-1095

Fuhrman, J. A., Azam, F. (1982). Thymidine incorporation as a measure of heterotrophic bacterioplankton production in marine surface waters: evaluation and field results. Mar. Biol. 66: 109-120

Isao, K., Hara, S., Terauchi, K., Kogure, K. (1990). Role of submicrometre particles in the ocean. Nature, Lond. 345 : 242-244

Jeffrey, W. H., Paul, J. H., Cazares, L. H., Deflaun, M. F., David, A. W. (1990). Correlation of nonspecific macromolecular labeling with environmental parameters during $\left[{ }^{3} \mathrm{H}\right]$ thymidine incorporation in the waters of southwest Florida. Microb. Ecol. 20: 21-35

Karl, D. M., Bailiff, M. D. (1989). The measurement and distribution of dissolved nucleic acids in aquatic environments. Limnol. Oceanogr. 34: 543-558

Luria, S. E., Williams, R. C., Backus, R. C. (1951). Electron micrographic counts of bacteriophage particles. J. Bacteriol. $61 \quad 179-188$

McManus, G. B., Fuhrman, J. A. (1988). Control of marine bacterioplankton populations: measurement and significance of grazing. Hydrobiologia 159: 51-62

Moriarty, D. J. W. (1986). Measurement of bacterial growth rates in aquatic systems from rates of nucleic acid synthesis. In: Marshall, K. C. (ed.) Advances in microbial ecology, Vol. 9. Plenum Press, New York, p. 245-292

Pace, M. L. (1988). Bacterial mortality and the fate of bacterial production. Hydrobiologia 159: 41-49

Paul, J. H., DeFlaun, M. F., Jeffrey, W. H., David, A. W. (1988) Seasonal and diel variability in dissolved DNA and in microbial biomass and activity in a subtropical estuary Appl. environ. Microbiol. 54: 718-727

Porter, K., Feig, Y S. (1980). The use of DAPI for identifying and counting aquatic microflora. Limnol. Oceanogr 25: 943-948

Proctor, L. M. Fuhrman, J. A. (1990). Viral mortality of marine bacteria and cyanobacteria. Nature, Lond. 343: 60-62

Riemann, B., Bell, R. T (1990). Advances in estimating bacterial biomass and growth in aquatic systems. Arch. Hydrobiol. 118: 385-402

Riemann, B., Bjornsen, P. K., Newell, S., Fallon, R. (1987). Calculation of cell production of coastal marine bacteria based on measured incorporation of $\left[{ }^{3} \mathrm{H}\right]$ thymidine. Limnol. Oceanogr 32: 471-476

Sanders, R. W., Porter, K. G. (1986). Use of metabolic inhibitors to estimate protozooplankton grazing and bacterial production in a monomictic eutrophic lake with an anaerobic hypolimnion. Appl. environ. Microbiol. 52: 101-107

Servais, P., Billen, G., Rego, J. V. (1985). Rate of bacterial mortality in aquatic environments. Appl. environ. Microbiol. 49: 1448-1454

Servais, P., Billen, G., Martinez, J., Vives-Rego, J. (1989) Estimating bacterial mortality by the disappearance of ${ }^{3} \mathrm{H}$ labeled intracellular DNA. FEMS Microb. Ecol. 62 $119-126$

Sherr, B. F., Sherr, E. B., Andrew, T L., Fallon, R. D., Newell, S. Y. (1986). Trophic interactions between heterotrophic Protozoa and bacterioplankton in estuarine water analyzed with selective metabolic inhibitors. Mar. Ecol. Prog Ser. 32: 169-179

Sherr, B. F., Sherr, E. B., Pedròs-Aliò, C. (1989). Simultaneous measurement of bacterioplankton production and proto- 
zoan bacterivory in estuarine water Mar. Ecol. Prog. Ser 54: $209-219$

Sieburth, J. McN., Johnson, P. W., Hargraves, P. E. (1988). Ultrastructure and ecology of Aureococcus anophagefferens gen. et sp. nov. (Chrysophyceae): the dominant picoplankter during a bloom in Narragansett Bay, Rhode Island, summer 1985. J. Phycol. 24: 416-425

Sugimura, Y. Suzuki, Y. (1988). A high-temperature catalytic oxidation method for the determination of non-volatile dissolved organic carbon in seawater by direct injection of liquid sample. Mar Chem. 24: 105-131

Symonds, N. D. (1957). Effects of ultraviolet light during the second half of the latent period on bacteria infected with Phage T2. Virology 3: 485-495

Symonds, N. D. (1968). One-step growth curve and the Doermann experiment. In: Clowes, R. C., Hayes, W. (eds.) Experiments in microbial genetics. Blackwell Scientific Publications, Oxford, p. 75-78

This article was presented by J. Gray, Oslo, Norway
Taylor, G. T., Pace, M. L. (1987). Validity of eucaryote inhibitors for assessing production and grazing mortality of marine bacterioplankton. Appl. environ. Microbiol. 53: 119-128

Torrella, F. Morita, R. Y (1979). Evidence for a high incidence of bacteriophage particles in the waters of Yaquina Bay, Oregon: ecological and taxonomical implications. Appl. environ. Microbiol. 37: 774-778

Tremaine, S. C., Mills, A. L. (1987a). Inadequacy of the eucaryote inhibitor cycloheximide in studies of protozoan grazing on bacteria at the freshwater-sediment interface. Appl. environ. Microbiol. 53: 1969-1972

Tremaine, S. C., Mills, A. L. (1987b). Tests of the critical assumptions of the dilution method for estimating bacterivory by microeucaryotes. Appl. environ. Microbiol. 53: 2914-2921

Wright, R. T., Coffin, R. B. (1984). Measuring microzooplankton grazing on planktonic marine bacteria by its impact on bacterial production. Microb. Ecol. 10: 137-149

Manuscript first received: December 5, 1990 Revised version accepted: March 19, 1991 